\title{
Eosinophils and Th2 immunity: contemporary insights
}

\section{Citation}

Spencer, Lisa A, and Peter F Weller. 2010. Eosinophils and Th2 Immunity: Contemporary Insights. Immunol Cell Biol 88, no. 3: 250-256. doi:10.1038/icb.2009.115.

\section{Published Version}

doi:10.1038/icb.2009.115

\section{Permanent link}

http://nrs.harvard.edu/urn-3:HUL.InstRepos:33730188

\section{Terms of Use}

This article was downloaded from Harvard University's DASH repository, and is made available under the terms and conditions applicable to Other Posted Material, as set forth at http:// nrs.harvard.edu/urn-3:HUL.InstRepos:dash.current.terms-of-use\#LAA

\section{Share Your Story}

The Harvard community has made this article openly available.

Please share how this access benefits you. Submit a story.

\section{Accessibility}




\title{
Eosinophils and Th2 immunity: contemporary insights
}

\author{
Dr. Lisa A Spencer and Peter F Weller \\ Department of Medicine, Beth Israel Deaconess Medical Center, Harvard Medical School, \\ Boston, MA, USA
}

\begin{abstract}
Eosinophils, innate immune leukocytes elicited by Th2 cells, have long been associated with the effector arm of Th2 immune responses. However, accumulating data over the past decade reveal a much more dynamic picture of Th2 immunity, where eosinophils are present very early in response to Th2-inducing agents and function in the initiation of Th2 immunity. Here we discuss recent data showing immune functions of eosinophils distinct from their previously appreciated tissue- and helminth-destructive capacities, providing strong evidence for a new paradigm of Th2 immunity defined by a dynamic interplay between eosinophils and $\mathrm{T}$ cells.
\end{abstract}

\section{Keywords}

Th2; eosinophil; allergy; helminth

\section{EOSINOPHILS AND TH2 IMMUNITY: A NEW PARADIGM}

Eosinophils have long been associated with Th2 immunity, elicited in response to helminth infections and atopic diseases. Traditional dogma held that during the course of Th2 responses, eosinophils, elicited by interleukin (IL)-5-secreting Th2 lymphocytes, entered tissue sites of localized helminths or allergic inflammation and released lipid mediators and granule-stored cationic proteins, with anthelminthic and, in the case of allergic diseases, tissue-destructive, consequences. This view held that eosinophils functioned strictly as an effector arm of Th2 immunity, potentially effective weapons against some parasites, and misguided purveyors of tissue damage in allergy. However, within the past decade, complimentary studies from several laboratories have probed the immunobiology of eosinophils, and have uncovered functional capacities for eosinophils incompatible with the view that eosinophils function solely as terminal effector cells. Taken together, more recent findings reveal a new paradigm for the relationship of eosinophils with Th2 immunity, based on a dynamic, self-perpetuating interplay between eosinophils and Th2 lymphocytes, where eosinophils contribute both to the initiation and effector functions of Th2 immunity.

\section{Mouse models of eosinophil deficiencies}

Major factors involved in eosinophil differentiation and trafficking include IL-5 and eotaxins 1, 2 and 3 (CCL11, CCL24 and CCL26, respectively). IL-5 is critical for eosinophil differentiation within bone marrow, ${ }^{1-3}$ and the eotaxins are key chemoattractants involved in the selective recruitment of eosinophils into tissues. ${ }^{1,4}$ The importance of these molecules to the basic functioning of eosinophils in vivo is evidenced by the substantial overproduction of eosinophils in IL-5 overexpressing transgenic ( $\mathrm{Tg}$ ) mice, and conversely the significantly

(C) 2010 Australasian Society for Immunology Inc. All rights reserved

Correspondence: Dr LA Spencer, Department of Medicine, Beth Israel Deaconess Medical Center, Harvard Medical School, 330 Brookline Avenue, E/CLS Room 935, Boston, MA 02215, USA. lspencer@bidmc.harvard.edu. 
reduced production of eosinophils in genetically deficient $\mathrm{IL}-5^{-/}$mice. Similarly, eotaxin-1-deficient mice, or mice deficient in the receptor for eotaxins (CCR3), exhibit a severe defect in eosinophil recruitment from the blood into tissues, a phenotype made more complete by the combined deletion of IL- 5 and eotaxin (reviewed in Rothenberg and $\operatorname{Hogan}^{5}$ ). The above strains of genetically engineered mice have been enormously valuable in deciphering in vivo consequences of eosinophil functions, and studies using these models are discussed in greater detail below. However, the persistence of residual eosinophils in the knockout or antibody-depleted animals, especially within tissues, limits the extent to which these Tg models are capable of reversing all eosinophil-mediated effects. In addition, the potential for secondary consequences on other cell types can make it difficult to draw absolute conclusions. These caveats were recently overcome with the development of two independent strains of eosinophil-deficient mice.

For the creation of dblGATA $1^{-/-}$eosinophil-deficient mice, Yu et al. ${ }^{6}$ deleted a highaffinity GATA binding site in the GATA1 promoter of BALB/c mice, selectively ablating the eosinophil lineage but leaving other GATA1-dependent lineages intact. At around the same time, Lee et al. ${ }^{7}$ used the strategy of expressing diphtheria toxin A under the control of the eosinophil peroxidase promoter to create $P H I L^{-1-}$ eosinophil null mice on the C57BL/6 background. In vivo studies of allergic inflammation and helminth infections in these eosinophil-deficient mice have allowed, for the first time, clear demonstrations of nonredundant functions for eosinophils, particularly in airway remodeling events, ${ }^{7,8}$ supporting the paradigm shift in our view of eosinophilic contributions to allergic diseases. New questions have also arisen from some apparent discrepancies between these mouse models. For example, C57BL/6 PHIL mice subjected to ovalbumin (OVA) sensitization and airways challenge exhibited a significant defect in the generation of Th2 cells and Th2associated cytokines, and in the recruitment of effector Th2 cells to the lungs, manifest in diminished mucus production and improved airway hyperreactivity. ${ }^{7}$ In contrast, BALB/c GATA $1^{-/}$mice subjected to a similar OVA sensitization and challenge protocol mounted a Th2 response comparable to that observed in wild-type (WT) mice, and showed no changes in airway hyperreactivity. ${ }^{8}$ This apparent discrepancy at least partially reflects genetic differences introduced by the different background strains of the eosinophil null mice, a theory supported by work from Walsh et al. ${ }^{9}$ showing a diminished Th2 response following OVA sensitization and airway challenge of GATA $1^{-/-}$mice backcrossed to the C57BL/6 background. Observed differences between these models are discussed below in greater detail within the context of specific eosinophil immunomodulatory functions.

\section{Eosinophil functions relevant to the generation of Th2 immunity}

Establishing a Th2 immune response involves the coordinated efforts of two critical components: $\mathrm{CD}^{+} \mathrm{T}$ cells, through interactions with cognate antigen-specific antigenpresenting cells (APCs), are polarized within secondary lymphoid tissue to a Th2 phenotype; and Th2-differentiated effector cells are recruited to affected tissue sites. Studies in humans and mice have elucidated three key functions of eosinophils that may contribute to the induction of Th2 immunity by promoting Th2 differentiation and/or recruiting effector Th2 cells to tissue sites. (1) Eosinophils provide sources of Th2-inducing cytokines (principally IL-4 and IL-13) very early in an immune response within tissues and lymph nodes; (2) eosinophils directly process and present antigen to naive or primed $\mathrm{CD} 4^{+} \mathrm{T}$ cells, promoting Th2 differentiation and clonal proliferation and (3) eosinophils secrete chemoattractants that specifically recruit $\mathrm{Th} 2$ effector cells to inflamed tissues. That these capacities represent critical and nonredundant functions of eosinophils in the development of Th2 responses, in at least some genetic settings, is evidenced by acute and chronic mouse models of allergic inflammation in eosinophil-deficient mice, in which the absence of eosinophils is 
accompanied by attenuated Th2 immunity, ${ }^{7,9-11}$ and adoptive transfer of eosinophils alone ${ }^{9}$ or in parallel with antigen-specific $\mathrm{T}$ cells ${ }^{10}$ rescues efficient $\mathrm{Th} 2$ responses.

Here we discuss the findings to date concerning the immunomodulatory potential of eosinophils. There is some question as to how closely murine eosinophils mimic their human counterparts, particularly with respect to degranulation events. Therefore, we will highlight those findings validated in human cells throughout the text. Moreover, we will discuss what is missing from our understanding of the role(s) of eosinophils in promoting Th2 immunity, and future directions of the field.

\section{EOSINOPHILS INITIATE TH2 CELL POLARIZATION}

Murine models of parasite or allergen challenge support a role(s) for eosinophils in the efficient generation of Th2-polarized T cells. IL-13 production by Th2 lymphocytes of IL-5/ eotaxin double-knockout mice is attenuated in response to aerosolized OVA, and the defect in Th2 IL-13 production is rescued on eosinophil reconstitution. ${ }^{12} \mathrm{Th} 2$ cytokines IL-4 and IL-13 (but not IL-5), and Th2-associated pathological sequelae (that is, increased airway hyperreactivity and mucus production) are diminished in $\mathrm{CCR}^{-1-}$ mice and in eosinophildeficient dblGATA $1^{-/-}$mice challenged with intranasal Aspergillus fumigatus. ${ }^{11}$ Likewise, Th2 cytokine and asthma outcomes are attenuated in both eosinophil-deficient PHIL ${ }^{7,10}$ and dblGATA1 $1^{-1-9}$ mice on the C57BL/6 genetic background, and full restoration of Th2 immunity is achieved by reconstitution of eosinophils alone ${ }^{9}$ or in combination with antigen-specific T cells. ${ }^{10}$ Of note, in contrast to results with dblGATA1 ${ }^{-/}$eosinophildeficient mice backcrossed onto the C57BL/6 background, acute OVA airway challenge ${ }^{8}$ or infection with Nippostrongylus brasiliensis ${ }^{13}$ of dblGATA $1^{-/}$mice generated on the BALB/c background elicited comparable levels of Th2 cells and associated cytokines in lymph nodes and lungs compared with WT counterparts. One might speculate from these findings that the relative in vivo dispensability of the Th2-promoting functions of eosinophils is genetically determined. However, subsequent studies suggest a greater level of complexity that call into question as well the specific allergen used, as dblGATA $1^{-/-}$ mice on the BALB/c background exhibit a diminished $\mathrm{Th} 2$ response following intranasal challenges with $A$. fumigatus. ${ }^{11}$

Although the jury is still out about specific genetic and physiological conditions under which eosinophils are required for eliciting Th2 immunity, functional capacities by which eosinophils instruct Th2 polarization are established, and include very rapid secretion of immune-polarizing cytokines, secretion of non-cytokine factors that modulate $\mathrm{T}$ cell or dendritic cell (DC) activities and direct antigen presentation functions, as described in the following subsections.

\section{Eosinophils provide a rapid source of Th2-inducing cytokines}

In vitro studies show the overwhelming effect immunomodulatory cytokines have on promoting T-cell differentiation. For induction of Th2 polarization IL-4 is a critical driving force in vitro, ${ }^{14-16}$ and studies in IL-4 ${ }^{-/}$, IL-4/IL-13-/- ${ }^{-1 L}-4 \mathrm{Ra}^{-/-}$and Stat6 ${ }^{-/-}$mice implicate activation of Stat 6 by signaling through IL-4Ra bound by IL-4 or IL-13 in the in vivo generation of Th2 immunity. ${ }^{17,18}$ IL-6 has also been shown to promote Th2 polarization, through induction of naive T-cell-derived IL-4. ${ }^{19}$ Th2-polarizing cytokines may be supplied directly by the APC, or by accessory cells at the site of T-cell priming. Findings from several laboratories show rapid secretion of eosinophil-derived IL-4, IL-13 and IL-6, as discussed below. Of note, Th2-associated responses are not entirely ablated in the absence of IL-4 and IL-13; a subset of CD4 ${ }^{+}$, IL-4-producing cells are elicited and accumulate within lymph nodes of IL-4Ra ${ }^{-1-}$ mice in response to infection with $N$. brasiliensis, and are likely natural killer (NK) T cells. $^{20}$ 
Studies in mice reveal constitutive expression of Th2-associated IL-4 and IL-13 mRNAs early in eosinophil ontogeny, early production of IL-4 and IL-13 by mature eosinophils, ${ }^{21}$ and a constitutively active IL-4 gene locus in circulating eosinophils. ${ }^{22,23}$ Eosinophils are rapidly recruited in response to Th2-eliciting pathogens or allergens, even in the absence of adaptive immunity, ${ }^{23,24}$ and are the dominant IL-4-producing cell type within the peritoneal cavities of mice inoculated with Schistosoma mansoni eggs ${ }^{25}$ and in the airways of mice infected with $N$ brasiliensis or challenged with intranasal OVA. ${ }^{13,22}$ Early tissue sources of eosinophil-derived IL-4 may act on resident DCs, provoking these APCs to a Th2-inducing phenotype. In addition, observations of eosinophil migration from airways into T-cell zones of draining lymph nodes ${ }^{26-30}$ reveal another microenvironment within which eosinophilderived IL-4 might directly promote Th2 polarization.

Importantly, the capacity for eosinophil secretion of Th2-inducing cytokines is validated in studies of human eosinophils. Human blood eosinophils store quantities of preformed cytokines, localized predominantly to intracellular granules. ${ }^{31,32}$ This storehouse of proteins, available for immediate secretion, sets eosinophils apart from most other cytokine-secreting leukocytes (including NK T cells and lymphocytes) requiring de novo synthesis, or at least protein translation, for their cytokine secretory responses. Human eosinophils respond to multiple chemokine, cytokine and microbial stimuli with the very rapid and stimulusspecific secretion of a plethora of cytokines, including IL-4, IL-13 and IL-6. ${ }^{31-37}$

Non-eosinophil innate cell sources of IL-4 include NK T cells, $\gamma \delta$ T cells, basophils and mast cells. Of these, NK T, $\gamma \delta \mathrm{T}$ cells and mast cells reside primarily within tissues, whereas eosinophils and basophils are recruited from the blood into affected tissues. (A notable exception being the gastrointestinal tract, where resident eosinophils are also found.) Delineation of nonredundant contributions of these distinct cell types to the induction of Th2 polarization is hampered somewhat by likely overlapping and interrelated functions as well as insufficient reagents to eliminate selectively each of the specific innate immune cell types, and further clouded by clear fundamental differences between cells of mouse and human origin. Nonetheless, human eosinophils stand out in this group at least about their intracellular content of preformed cytokine proteins, available for immediate release without the need for de novo protein synthesis. Although $\gamma \delta \mathrm{T}$ cells and NK T cells may provide tissue sources of IL-4, cytokine production in these cells relies on stimulated de novo synthesis or translation of nascent mRNA. The extent to which basophils (particularly human basophils) are capable of very rapid secretion of preformed cytokines has yet to be fully explored, but early studies suggest that IL-4 is likely rapidly secreted, whereas secretion of IL-13 from human basophils is delayed (reviewed in Schroeder ${ }^{38}$ ).

Recently, another cytokine has captured attention for its potential role in augmenting Th2 immune responses. IL-25, a member of the IL-17 family of cytokines, has been shown to promote Th2 differentiation of naive $\mathrm{CD}^{+}{ }^{+} \mathrm{T}$ cells through an IL-4- and STAT6-dependent mechanism. ${ }^{39}$ Eosinophils and basophils from normal and atopic patients have been shown to produce and secrete IL-25, suggesting eosinophil-derived IL-25 may represent an additional means by which eosinophils contribute to the initiation of Th2 responses. ${ }^{40} \mathrm{Th} 2$ central memory cells express high levels of the receptor for IL-25, and IL-25 stimulation of Th2 memory cells promotes T-cell expansion and Th2 cytokine production. ${ }^{40}$ A potential function for eosinophils in the activation of Th2 memory cells is discussed below.

\section{Non-cytokine, eosinophil-derived factors affecting immunomodulation}

In addition to the secretion of Th2-polarizing cytokines, eosinophils also secrete mediators with the potential to promote $\mathrm{Th} 2$ immunity indirectly through actions on other cell types. One such eosinophil-derived factor with the potential to shift the balance toward Th2 immunity is indoleamine 2,3-dioxygenase (IDO), an enzyme that catalyzes the oxidative 
catabolism of tryptophan to kynurenines. Kynurenines inhibit proliferation and promote apoptosis in T cells, ${ }^{41}$ preferentially in Th1 cells. ${ }^{42,43}$ Human eosinophils from the blood of atopic donors constitutively express IDO, as did eosinophils infiltrating the lungs and pulmonary lymphoid tissue of a patient with Churg-Strauss syndrome, and eosinophils from the thymi of children. ${ }^{44,45}$

Another immunomodulating factor generated by human eosinophils is eosinophil-derived neurotoxin (EDN), an RNase A superfamily member. In addition to its antiviral properties, EDN is a chemoattractant ${ }^{46}$ and activator ${ }^{47}$ of DCs. In vivo, EDN-activated DCs enhance Th2 responses through a TLR2-dependent mechanism, identifying EDN as an innate immune 'alarmin'. ${ }^{48}$ Therefore, eosinophil secretion of EDN represents a capacity for eosinophils to instruct adaptive immunity by providing a 'danger signal' to nearby DCs.

\section{Eosinophils as antigen-presenting cells}

The minimum requirements for antigen presentation are the ability to internalize, process and present antigenic peptides within the context of surface-expressed major histocompatibility complex (MHC) II, the capacity to provide co-stimulatory signals to T cells through surface expression of molecules such as CD80, CD86 and CD40, and availability to physically interact with $\mathrm{CD}^{+}{ }^{+} \mathrm{T}$ cells. Antigen-pulsed eosinophils administered intratracheally into mice migrate to draining thoracic lymph nodes and localize primarily within T-cell zones. ${ }^{26,27,29}$ Similarly, following airway allergen challenge of mice, eosinophils traffic to and accumulate within regional lymph nodes, where they upregulate molecules associated with antigen presentation (that is, MHC II, CD86 and CD54), ${ }^{28}$ and eosinophils recovered from mice infected with Brugia malayi exhibit elevated MHC II surface expression. ${ }^{49}$ These findings show that in vivo eosinophils are physically prepared and anatomically positioned to function as APCs. In vitro, murine eosinophils process and present antigen to T-cell clones and hybridomas, ${ }^{50}$ and to Ag-primed and naive $\mathrm{CD}^{+} \mathrm{T}$ cells. ${ }^{51}$ In vivo, antigen-pulsed eosinophils transferred into WT recipients are sufficient to prime naive mice and boost immunized mice for subsequent infection with Strongyloides stercoralis, ${ }^{52}$ and antigen-loaded eosinophils instilled intratracheally into WT recipient mice are sufficient for the expansion of Th2 cells within endobronchial lymph nodes, regardless of whether the donor eosinophils were recovered directly from the airways of OVAsensitized and challenged mice, ${ }^{27}$ or pulsed ex vivo with OVA antigen. ${ }^{53}$ Thus, in vitro and in vivo, murine eosinophils function as APCs to acquire, process and present parasitic and allergenic antigens, initiating antigen-specific Th2 cell expansion.

Of note, in contrast to the published reports described above, van Rijt et al. ${ }^{29}$ found that eosinophils recovered from the bronchoalveolar lavage fluid of OVA-challenged mice were incapable of stimulating naive T-cell expansion within draining lymph nodes of recipient mice. A likely explanation for the discrepancies between this one conflicting report and the others showing the sufficiency of eosinophils to induce naive T-cell activation is the difference in the isolation procedure used to procure the donor eosinophil population. In the van Rijt paper, eosinophils recovered from bronchoalveolar lavage fluid were treated with ammonium chloride, a standard procedure for lysing red blood cells. ${ }^{29}$ However, in addition to red blood cell lysis, ammonium chloride diminishes lysosomal antigen processing and inhibits MHC II-dependent antigen presentation, ${ }^{54,55}$ raising the possibility that through red blood cell lysis, these investigators may have inadvertently incapacitated the eosinophil input population. In support of this interpretation, Wang et al. ${ }^{53}$ showed that antigenexposed eosinophils transferred into recipient mice were sufficient to prime naive $\mathrm{T}$ cells, and that this capacity was abrogated by earlier exposure of the eosinophils to ammonium chloride. 
Importantly, these findings are validated by studies with human eosinophils. Although circulating eosinophils from healthy donors are generally devoid of surface MHC II expression, with appropriate cytokine stimulation human blood eosinophils are induced to express antigen presentation machinery, including MHC II molecules ${ }^{56}$ and the costimulatory molecules $\mathrm{CD} 86^{57}$ and CD40. ${ }^{58}$ In vitro, passage through a pulmonary microvascular endothelial cell monolayer elicited MHC II expression by human peripheral blood eosinophils. ${ }^{59}$ In vivo expression of MHC II has been further confirmed on eosinophils isolated from the bronchoalveolar lavage fluid of a patient with chronic eosinophilic pneumonia, ${ }^{60}$ from the sputum of patients with asthma, ${ }^{61}$ and in eosinophils recovered from patients with allergic rhinitis following segmental lung allergen challenge. ${ }^{62}$ Notably, eosinophils exposed to superantigen ${ }^{63,64}$ or tetanus toxoid ${ }^{65}$ induced antigenspecific T-cell proliferation in in vitro co-cultures. In the latter case, T-cell expansion was abrogated by fixation of eosinophils before (but not following) antigenic exposure, indicating eosinophil processing of antigens is required for successful priming. ${ }^{65}$

In the above-mentioned studies, the $\mathrm{CD} 4^{+} \mathrm{T}$ cells expanded through eosinophil APC functions exhibited a Th2 phenotype. Whether this observation reveals a true proclivity of eosinophils toward Th2 induction, or reflects the particularity of the choice of antigen (for example, helminthic parasites and allergens) or anatomic location (mucosal surfaces of the airways and GI tract) has yet to be elucidated. The latter explanation is likely correct, as human blood eosinophils infected ex vivo with rhinovirus promoted Th1-associated interferon- $\gamma$ secretion from autologous (but not allogeneic), virus-specific T cells. ${ }^{66}$ However, some circumstantial evidence suggests the default programming of eosinophils might predispose toward Th2 immunity. First, as discussed above, $\mathrm{CD} 4^{+} \mathrm{T}$-cell polarization is heavily influenced by the immunomodulatory cytokine(s) present at the time of priming. Human blood eosinophils, although preloaded with cytokines capable of eliciting either Th1 (that is, IL-12) or Th2 (that is, IL-4, IL-13, IL-6) polarization, preferentially secreted Th2inducing cytokines on exposure to Th1- or Th2-immunomodulatory cytokine stimuli. ${ }^{31}$

In addition to the presence of specific immunomodulatory cytokines within the microenvironment where T-cell priming takes place, accessory molecules expressed by APCs provide critical signals (commonly referred to as 'signal 3') for the specific polarization of $\mathrm{CD}^{+} \mathrm{T}$ cells toward Th1, Th2 or Th17 fate. Notch ligands have been identified as one such class of polarizing molecules, with APC expression of Jagged1 instructing Th2 differentiation independently of IL-4 and STAT6, ${ }^{67,68}$ APC expression of Delta 1 promoting development of Th1 progeny, ${ }^{69}$ and APC Delta 4 expression promoting polarization toward Th $1{ }^{67}$ or Th17. ${ }^{70}$ Differential expression of Notch ligands has been proposed to explain discrepancies in the polarization potential of immature versus mature DCs. Liotta et al. ${ }^{68}$ showed that immature DCs (which classically polarize T cells toward a 'default' Th2 fate) express surface Jagged1 molecules, whereas TLR-stimulated maturation of DCs in response to microbial signals caused a replacement of Jagged1 with expression of Delta 1 and a concomitant induction of Th1 polarization. In vivo significance of Notch signaling, specifically to Th2 immunity, is revealed in a murine model of airway inflammation, where Th2 responses are dependent on an intact, Jagged1-dependent Notch signaling pathway. ${ }^{71}$ Of note, we have recently shown that human eosinophils constitutively express Jagged $1 \mathrm{mRNA}$ and protein while in circulation, ${ }^{72}$ a finding that may further support the contention that promotion of Th2 immunity is the 'default' setting of human eosinophils, and that they, like immature DCs, might be 'educated' to alter their Notch ligand repertoire through specific pathogen-derived signals to provoke Th1 immunity.

\section{Summary}

It is clear from the above-described studies that eosinophils are fully competent to participate in $\mathrm{CD}^{+} \mathrm{T}$-cell instruction toward a Th2 phenotype. Eosinophils store and, on 
stimulation, rapidly secrete preformed Th2-initiating cytokines, including IL-4, IL-13, IL-6 and IL-25. In addition to immunomodulatory cytokines, eosinophils are sources of alarmins, the secretion of which provides a danger signal to local DCs. Further, eosinophils are fully competent APCs, directly activating naive or previously primed $\mathrm{CD} 4^{+} \mathrm{T}$ cells. How widespread a requirement the Th2-initiating capacities of eosinophils represent in response to specific infectious agents or allergens remains unclear. Eosinophil-dependent initiation of $\mathrm{Th} 2$ differentiation is critically required in vivo for the generation of protective Th2 immunity to $S$. stercoralis. ${ }^{51,52}$ In contrast, Th2 immunity against an aerosolized OVA challenge is restored by eosinophil reconstitution of $\mathrm{dblGATA}^{-/-} \mathrm{C} 57 \mathrm{BL} / 6$ recipients, even when eosinophil reconstitution occurs after OVA sensitization (but before OVA challenge). ${ }^{9}$ Elucidating infectious and/or genetic conditions under which innate immune cells in general and eosinophils in particular might be critical adjuncts to the well-established roles of professional APCs (that is, DCs) is currently an important area of research. Notably, the existence of preformed pools of Th1-inducing cytokines and the capacity of eosinophils presenting viral antigens to instruct Th1 differentiation suggest that eosinophils are not solely committed to Th2 immunity, but are also fully competent to drive immunity toward Th1 under the appropriate conditions.

\section{EOSINOPHILS RECRUIT TH2 EFFECTOR CELLS}

As discussed above, effective Th2 immunity requires not only efficient induction of Th2 differentiation, but also the recruitment of Th2 effector cells to the site of infection or allergen deposition and enhancement of Th2 cell activities within tissue sites. Eosinophils, through the secretion of Th2-specific chemokines and factors that specifically enhance Th2 effector functions, promote the maintenance of efficient $\mathrm{Th} 2$ immunity within tissues.

\section{Eosinophil-derived chemokines are required for Th2 effector cell recruitment}

Cytokines and chemokines secreted by Th2 effector cells, most prominently IL-5 and eotaxins, enhance eosinophil differentiation in the bone marrow and recruit eosinophils to tissue sites, respectively (reviewed in Rothenberg and Hogan ${ }^{5}$ ), suggesting Th2 lymphocytes promote eosinophilia and promote eosinophil recruitment into tissues. However, in vivo studies designed to examine Th2-associated responses revealed an earlier wave of eosinophil influx into inflammatory sites preceding that of lymphocytes in WT mice, ${ }^{13,22,25}$ even in the absence of adaptive immunity. ${ }^{23,24}$ Notably, T-cell recruitment and accumulation into the airways of acute or chronically allergen-challenged mice was attenuated in mice made deficient or devoid of eosinophils through CCR 3 depletion, ${ }^{11}$ genetic eosinophil ablation ${ }^{7,10}$ or genetic eosinophil deficiency. ${ }^{9,11}$ Inefficient $\mathrm{Th} 2$ cell recruitment was associated with diminished pulmonary expression of the Th2-associated cytokines IL-4 and IL-13, ${ }^{7,9-11}$ and attenuation of pathological outcomes normally associated with $\mathrm{Th} 2$ immunity (that is, mucus production).$^{7,11}$ Importantly, Jacobsen et al. ${ }^{10}$ showed that observed deficiencies in Th2 cell recruitment stemmed from more than a defect in Th2 differentiation. Adoptive transfer of Th2-polarized T cells alone was insufficient to restore Th2 inflammatory lung responses; ${ }^{10}$ transfer of eosinophils was required to rescue the WT phenotype of OVA-induced airway inflammation in both PHIL ${ }^{10}$ and dblGATA1 ${ }^{-/-9}$ eosinophil-deficient hosts.

Despite the confirmatory findings of Jacobsen et al..$^{10}$ and Walsh et al..$^{9}$ of a requirement for eosinophil-derived chemokines in the restoration of efficient Th2 effector cell recruitment, the specific chemokines implicated in the two studies were different. In their study, Walsh et al. ${ }^{9}$ noted deficient eotaxin 1 and 2 (CCL11 and CCL24) production in response to OVA airway challenge associated with the lack of eosinophils in $\mathrm{dblGATA}^{-1-}$ mice, and showed that the addition of exogenous of eotaxin 1 was sufficient to restore Th2 cell influx and Th2associated cytokines. In contrast, using the PHIL eosinophil-deficient mice Jacobsen et al. found no significant deficiencies in the expression of allergen-elicited eotaxins, but rather 
noted diminished levels of CCL22 (MDC) and CCL17 (TARC). Intratracheal administration of eosinophils and antigen-specific Tg T cells restored the levels of CCL22 and CCL17 in parallel with a recovery of Th2 immunity. ${ }^{10}$ Although the apparent discrepancies between these different strains of eosinophil-deficient mice remain to be resolved, it would appear that eosinophil-dependent chemokine expression is critical for the efficient recruitment of Th2 effector cells in models of allergic airway inflammation. Although not yet as well delineated as the cytokine potential of eosinophils, eosinophils are known to secrete several chemokines with Th2-chemoattractive properties, including CCL22, CCL17, CCL11 (eotaxin 1), CXCL8 (IL-8), CXCL1 and CCL2 (MCP-1). ${ }^{9,10,37,73}$ Of note, chemoattractants associated with Th1 immunity are also secreted by eosinophils, including CXCL9 and CXCL10. ${ }^{37}$

\section{Eosinophils may enhance Th2 memory cell function}

In addition to secretion of T-cell chemoattractants, eosinophils may also participate in the enhancement of Th2 effector cell function within tissues. As noted above, activated eosinophils and basophils are sources of IL-25. ${ }^{40}$ Although receptors for IL-25 are expressed on naive T cells, and IL-25 signaling is implicated in promoting Th2 differentiation (see above), IL-25 receptors are more abundantly expressed on Th2 memory cells, and receptor expression levels are further augmented on activation of Th2 memory cells by T-cell receptor cross-linking or interactions with thymic stromal lymphopoietinactivated DCs. ${ }^{40} \mathrm{Th} 2$ memory cells are suggested to be the major cellular subset promoting chronic allergic inflammatory responses and the acute allergic response mounted on reexposure to allergens. ${ }^{74-76} \mathrm{IL}-25$ enhances $\mathrm{Th} 2$ polarization, proliferation and cytokine production (particularly IL-5) of Th2 memory cells, ${ }^{40}$ suggesting that eosinophil-derived IL-25 may augment Th2 effector functions.

\section{SYNTHESIS AND FUTURE DIRECTIONS}

The past decade has seen a tremendous advancement in our appreciation of eosinophils as not only terminal effector cells elicited by Th2 cells engaged in allergic and anthelminthic responses, but also as critical players in the initiation and maintenance of Th2 immunity. Recognition of preformed stores within eosinophils of immunomodulatory cytokines and chemokines, and demonstrations of the capacities of eosinophils for very rapid, stimulusinduced secretion of these factors, in conjunction with in vitro and in vivo demonstrations of antigen presentation capabilities of eosinophils reveal previously ill-appreciated activities of eosinophils pertinent to Th2 responses. Of note, in addition to intact eosinophils, the recent identification of the secretion competence of cell-free eosinophil granules suggests that eosinophil granules, deposited extracellularly in tissues, might themselves enhance Th2 immune responses in the absence of intact eosinophils. ${ }^{77}$ Fuller delineations of the capacities of extracellularly released eosinophil granules, as well as the in vivo significance(s) of free granules within tissue, are needed.

That some or all of these capacities of eosinophils fulfill non-redundant niches in Th2 immunity is shown by studies in newly derived eosinophil-deficient mice. However, due to the discrepancies arising between nonredundant eosinophil functions in different models of murine Th2-associated diseases, an important focus of future research will be the elucidation of the specific genetic and disease-related conditions under which eosinophil Th2augmenting activities are indispensable to the generation and/or maintenance of an efficient Th2 response. Of special interest will be the identification of specific microbial signals that elicit Th2-inducing functions of eosinophils.

Along these same lines, some Th2-promoting activities of eosinophils are shared with other innate immune cells. For example, mouse and human basophils also secrete Th2-associated 
cytokines (reviewed in Schroeder ${ }^{38}$ ), and murine basophils have recently been reported to function as APCs. ${ }^{78-80}$ Defining areas of redundancy between eosinophils and other innate immune cells is critical to the successful development of novel therapeutic approaches.

In conclusion, a substantial body of data from several different laboratories now clearly suggest a new paradigm of eosinophilic involvement in Th2 immunity, revealing a dynamic interplay between eosinophils and T cells (summarized in Figure 1). Not only are eosinophils elicited by Th2 effector cells and activated to secrete parasite-and tissuedestructive mediators, they are also critically involved in the initiation, regulation and maintenance of $\mathrm{Th} 2$ immunity.

\section{Acknowledgments}

This work was supported by NIH Grants AI020241 and AI051645.

\section{References}

1. Collins PD, Marleau S, Griffiths-Johnson DA, Jose PJ, Williams TJ. Cooperation between interleukin-5 and the chemokine eotaxin to induce eosinophil accumulation in vivo. J Exp Med. 1995; 182:1169-1174. [PubMed: 7561691]

2. Foster PS, Hogan SP, Ramsay AJ, Matthaei KI, Young IG. Interleukin 5 deficiency abolishes eosinophilia, airways hyperreactivity, and lung damage in a mouse asthma model. J Exp Med. 1996; 183:195-201. [PubMed: 8551223]

3. Hogan SP, Koskinen A, Foster PS. Interleukin-5 and eosinophils induce airway damage and bronchial hyperreactivity during allergic airway inflammation in BALB/c mice. Immunol Cell Biol. 1997; 75:284-288. [PubMed: 9243294]

4. Zimmermann N, Hershey GK, Foster PS, Rothenberg ME. Chemokines in asthma: cooperative interaction between chemokines and IL-13. J Allergy Clin Immunol. 2003; 111:227-242. quiz 43. [PubMed: 12589338]

5. Rothenberg ME, Hogan SP. The eosinophil. Annu Rev Immunol. 2006; 24:147-174. [PubMed: 16551246]

6. Yu C, Cantor AB, Yang H, Browne C, Wells RA, Fujiwara Y, et al. Targeted deletion of a highaffinity GATA-binding site in the GATA-1 promoter leads to selective loss of the eosinophil lineage in vivo. J Exp Med. 2002; 195:1387-1395. [PubMed: 12045237]

7. Lee JJ, Dimina D, Macias MP, Ochkur SI, McGarry MP, O’Neill KR, et al. Defining a link with asthma in mice congenitally deficient in eosinophils. Science. 2004; 305:1773-1776. [PubMed: 15375267]

8. Humbles AA, Lloyd CM, McMillan SJ, Friend DS, Xanthou G, McKenna EE, et al. A critical role for eosinophils in allergic airways remodeling. Science. 2004; 305:1776-1779. [PubMed: 15375268]

9. Walsh ER, Sahu N, Kearley J, Benjamin E, Kang BH, Humbles A, et al. Strain-specific requirement for eosinophils in the recruitment of T cells to the lung during the development of allergic asthma. $\mathrm{J}$ Exp Med. 2008; 205:1285-1292. [PubMed: 18490489]

10. Jacobsen EA, Ochkur SI, Pero RS, Taranova AG, Protheroe CA, Colbert DC, et al. Allergic pulmonary inflammation in mice is dependent on eosinophil-induced recruitment of effector $\mathrm{T}$ cells. J Exp Med. 2008; 205:699-710. [PubMed: 18316417]

11. Fulkerson PC, Fischetti CA, McBride ML, Hassman LM, Hogan SP, Rothenberg ME. A central regulatory role for eosinophils and the eotaxin/CCR3 axis in chronic experimental allergic airway inflammation. Proc Natl Acad Sci USA. 2006; 103:16418-16423. [PubMed: 17060636]

12. Mattes J, Yang M, Mahalingam S, Kuehr J, Webb DC, Simson L, et al. Intrinsic defect in T cell production of interleukin (IL)-13 in the absence of both IL-5 and eotaxin precludes the development of eosinophilia and airways hyperreactivity in experimental asthma. J Exp Med. 2002; 195:1433-1444. [PubMed: 12045241] 
13. Voehringer D, Reese TA, Huang X, Shinkai K, Locksley RM. Type 2 immunity is controlled by IL-4/IL-13 expression in hematopoietic non-eosinophil cells of the innate immune system. J Exp Med. 2006; 203:1435-1446. [PubMed: 16702603]

14. Hsieh CS, Heimberger AB, Gold JS, O'Garra A, Murphy KM. Differential regulation of T helper phenotype development by interleukins 4 and 10 in an alpha beta T-cell-receptor transgenic system. Proc Natl Acad Sci USA. 1992; 89:6065-6069. [PubMed: 1385868]

15. Seder RA, Paul WE, Davis MM, Fazekas de St Groth B. The presence of interleukin 4 during in vitro priming determines the lymphokine-producing potential of $\mathrm{CD}^{+}{ }^{+} \mathrm{T}$ cells from $\mathrm{T}$ cell receptor transgenic mice. J Exp Med. 1992; 176:1091-1098. [PubMed: 1328464]

16. Le Gros G, Ben-Sasson SZ, Seder R, Finkelman FD, Paul WE. Generation of interleukin 4 (IL-4)producing cells in vivo and in vitro: IL-2 and IL-4 are required for in vitro generation of IL-4producing cells. J Exp Med. 1990; 172:921-929. [PubMed: 2117636]

17. McKenzie GJ, Fallon PG, Emson CL, Grencis RK, McKenzie AN. Simultaneous disruption of interleukin (IL)-4 and IL-13 defines individual roles in T helper cell type 2-mediated responses. J Exp Med. 1999; 189:1565-1572. [PubMed: 10330435]

18. Urban JF Jr, Noben-Trauth N, Schopf L, Madden KB, Finkelman FD. Cutting edge: IL-4 receptor expression by non-bone marrow-derived cells is required to expel gastrointestinal nematode parasites. J Immunol. 2001; 167:6078-6081. [PubMed: 11714764]

19. Rincon M, Anguita J, Nakamura T, Fikrig E, Flavell RA. Interleukin (IL)-6 directs the differentiation of IL-4-producing CD4 ${ }^{+}$T cells. J Exp Med. 1997; 185:461-469. [PubMed: 9053446]

20. Noben-Trauth N, Shultz LD, Brombacher F, Urban JF Jr, Gu H, Paul WE. An interleukin 4 (IL-4)independent pathway for $\mathrm{CD}^{+}{ }^{+} \mathrm{T}$ cell IL-4 production is revealed in IL-4 receptor-deficient mice. Proc Natl Acad Sci USA. 1997; 94:10838-10843. [PubMed: 9380721]

21. Gessner A, Mohrs K, Mohrs M. Mast cells, basophils, and eosinophils acquire constitutive IL-4 and IL-13 transcripts during lineage differentiation that are sufficient for rapid cytokine production. J Immunol. 2005; 174:1063-1072. [PubMed: 15634931]

22. Voehringer D, Shinkai K, Locksley RM. Type 2 immunity reflects orchestrated recruitment of cells committed to IL-4 production. Immunity. 2004; 20:267-277. [PubMed: 15030771]

23. Shinkai K, Mohrs M, Locksley RM. Helper T cells regulate type-2 innate immunity in vivo. Nature. 2002; 420:825-829. [PubMed: 12490951]

24. Sabin EA, Pearce EJ. Early IL-4 production by non-CD4 ${ }^{+}$cells at the site of antigen deposition predicts the development of a T helper 2 cell response to Schistosoma mansoni eggs. J Immunol. 1995; 155:4844-4853. [PubMed: 7594487]

25. Sabin EA, Kopf MA, Pearce EJ. Schistosoma mansoni egg-induced early IL-4 production is dependent upon IL-5 and eosinophils. J Exp Med. 1996; 184:1871-1878. [PubMed: 8920874]

26. Shi HZ, Humbles A, Gerard C, Jin Z, Weller PF. Lymph node trafficking and antigen presentation by endobronchial eosinophils. J Clin Invest. 2000; 105:945-953. [PubMed: 10749574]

27. Shi HZ, Xiao CQ, Li CQ, Mo XY, Yang QL, Leng J, et al. Endobronchial eosinophils preferentially stimulate T helper cell type 2 responses. Allergy. 2004; 59:428-435. [PubMed: 15005767]

28. Duez C, Dakhama A, Tomkinson A, Marquillies P, Balhorn A, Tonnel AB, et al. Migration and accumulation of eosinophils toward regional lymph nodes after airway allergen challenge. $\mathbf{J}$ Allergy Clin Immunol. 2004; 114:820-825. [PubMed: 15480321]

29. van Rijt LS, Vos N, Hijdra D, de Vries VC, Hoogsteden HC, Lambrecht BN. Airway eosinophils accumulate in the mediastinal lymph nodes but lack antigen-presenting potential for naive $\mathrm{T}$ cells. J Immunol. 2003; 171:3372-3378. [PubMed: 14500630]

30. MacKenzie JR, Mattes J, Dent LA, Foster PS. Eosinophils promote allergic disease of the lung by regulating CD4(+) Th2 lymphocyte function. J Immunol. 2001; 167:3146-3155. [PubMed: 11544300]

31. Spencer LA, Szela CT, Perez SA, Kirchhoffer CL, Neves JS, Radke AL, et al. Human eosinophils constitutively express multiple Th1, Th2, and immunoregulatory cytokines that are secreted rapidly and differentially. J Leukoc Biol. 2009; 85:117-123. [PubMed: 18840671] 
32. Lacy P, Moqbel R. Eosinophil cytokines. Chem Immunol. 2000; 76:134-155. [PubMed: 10761309]

33. Woerly G, Lacy P, Younes AB, Roger N, Loiseau S, Moqbel R, et al. Human eosinophils express and release IL-13 following CD28-dependent activation. J Leukoc Biol. 2002; 72:769-779. [PubMed: 12377947]

34. Lacy P, Mahmudi-Azer S, Bablitz B, Hagen SC, Velazquez JR, Man SF, et al. Rapid mobilization of intracellularly stored RANTES in response to interferon-gamma in human eosinophils. Blood. 1999; 94:23-32. [PubMed: 10381494]

35. Lacy P, Moqbel R. Eokines: synthesis, storage and release from human eosinophils. Mem Inst Oswaldo Cruz. 1997; 92(Suppl 2):125-133. [PubMed: 9698924]

36. Tedla N, Bandeira-Melo C, Tassinari P, Sloane DE, Samplaski M, Cosman D, et al. Activation of human eosinophils through leukocyte immunoglobulin-like receptor 7. Proc Natl Acad Sci USA. 2003; 100:1174-1179. [PubMed: 12529506]

37. Liu LY, Bates ME, Jarjour NN, Busse WW, Bertics PJ, Kelly EA. Generation of Th1 and Th2 chemokines by human eosinophils: evidence for a critical role of TNF-alpha. J Immunol. 2007; 179:4840-4848. [PubMed: 17878383]

38. Schroeder JT. Basophils beyond effector cells of allergic inflammation. Adv Immunol. 2009; 101:123-161. [PubMed: 19231594]

39. Angkasekwinai P, Park H, Wang YH, Chang SH, Corry DB, Liu YJ, et al. Interleukin 25 promotes the initiation of proallergic type 2 responses. J Exp Med. 2007; 204:1509-1517. [PubMed: $17562814]$

40. Wang YH, Angkasekwinai P, Lu N, Voo KS, Arima K, Hanabuchi S, et al. IL-25 augments type 2 immune responses by enhancing the expansion and functions of TSLP-DC-activated Th2 memory cells. J Exp Med. 2007; 204:1837-1847. [PubMed: 17635955]

41. Terness P, Bauer TM, Rose L, Dufter C, Watzlik A, Simon H, et al. Inhibition of allogeneic T cell proliferation by indoleamine 2,3-dioxygenase-expressing dendritic cells: mediation of suppression by tryptophan metabolites. J Exp Med. 2002; 196:447-457. [PubMed: 12186837]

42. Gurtner GJ, Newberry RD, Schloemann SR, McDonald KG, Stenson WF. Inhibition of indoleamine 2,3-dioxygenase augments trinitrobenzene sulfonic acid colitis in mice. Gastroenterology. 2003; 125:1762-1773. [PubMed: 14724829]

43. Fallarino F, Grohmann U, Vacca C, Bianchi R, Orabona C, Spreca A, et al. T cell apoptosis by tryptophan catabolism. Cell Death Differ. 2002; 9:1069-1077. [PubMed: 12232795]

44. Odemuyiwa SO, Ghahary A, Li Y, Puttagunta L, Lee JE, Musat-Marcu S, et al. Cutting edge: human eosinophils regulate $\mathrm{T}$ cell subset selection through indoleamine 2,3-dioxygenase. $\mathrm{J}$ Immunol. 2004; 173:5909-5913. [PubMed: 15528322]

45. Tulic MK, Sly PD, Andrews D, Crook M, Davoine F, Odemuyiwa SO, et al. Thymic indoleamine 2,3-dioxygenase-positive eosinophils in young children: potential role in maturation of the naive immune system. Am J Pathol. 2009; 175:2043-2052. [PubMed: 19815714]

46. Yang D, Rosenberg HF, Chen Q, Dyer KD, Kurosaka K, Oppenheim JJ. Eosinophil-derived neurotoxin (EDN), an antimicrobial protein with chemotactic activities for dendritic cells. Blood. 2003; 102:3396-3403. [PubMed: 12855582]

47. Yang D, Chen Q, Rosenberg HF, Rybak SM, Newton DL, Wang ZY, et al. Human ribonuclease A superfamily members, eosinophil-derived neurotoxin and pancreatic ribonuclease, induce dendritic cell maturation and activation. J Immunol. 2004; 173:6134-6142. [PubMed: 15528350]

48. Yang D, Chen Q, Su SB, Zhang P, Kurosaka K, Caspi RR, et al. Eosinophil-derived neurotoxin acts as an alarmin to activate the TLR2-MyD88 signal pathway in dendritic cells and enhances Th2 immune responses. J Exp Med. 2008; 205:79-90. [PubMed: 18195069]

49. Mawhorter SD, Pearlman E, Kazura JW, Boom WH. Class II major histocompatibility complex molecule expression on murine eosinophils activated in vivo by Brugia malayi. Infect Immun. 1993; 61:5410-5412. [PubMed: 7901170]

50. Del Pozo V, De Andres B, Martin E, Cardaba B, Fernandez JC, Gallardo S, et al. Eosinophil as antigen-presenting cell: activation of $\mathrm{T}$ cell clones and $\mathrm{T}$ cell hybridoma by eosinophils after antigen processing. Eur J Immunol. 1992; 22:1919-1925. [PubMed: 1623930] 
51. Padigel UM, Lee JJ, Nolan TJ, Schad GA, Abraham D. Eosinophils can function as antigenpresenting cells to induce primary and secondary immune responses to Strongyloides stercoralis. Infect Immun. 2006; 74:3232-3238. [PubMed: 16714550]

52. Padigel UM, Hess JA, Lee JJ, Lok JB, Nolan TJ, Schad GA, et al. Eosinophils act as antigen presenting cells to induce immunity to Strongyloides stercoralis in mice. J Infect Dis. 2007; 196:1844-1851. [PubMed: 18190266]

53. Wang HB, Ghiran I, Matthaei K, Weller PF. Airway eosinophils: allergic inflammation recruited professional antigen-presenting cells. J Immunol. 2007; 179:7585-7592. [PubMed: 18025204]

54. Loss GE Jr, Sant AJ. Invariant chain retains MHC II class molecules in the endocytic pathway. J Immunol. 1993; 150:3187-3197. [PubMed: 8468464]

55. Ziegler HK, Unanue ER. Decrease in macrophage antigen catabolism caused by ammonia and chloroquine is associated with inhibition of antigen presentation to T cells. Proc Natl Acad Sci USA. 1982; 79:175-178. [PubMed: 6798568]

56. Lucey DR, Nicholson-Weller A, Weller PF. Mature human eosinophils have the capacity to express HLA-DR. Proc Natl Acad Sci USA. 1989; 86:1348-1351. [PubMed: 2919183]

57. Celestin J, Rotschke O, Falk K, Ramesh N, Jabara H, Strominger J, et al. IL-3 induces B7. 2 (CD86) expression and costimulatory activity in human eosinophils. J Immunol. 2001; 167:60976104. [PubMed: 11714768]

58. Ohkawara Y, Lim KG, Xing Z, Glibetic M, Nakano K, Dolovich J, et al. CD40 expression by human peripheral blood eosinophils. J Clin Invest. 1996; 97:1761-1766. [PubMed: 8601642]

59. Yamamoto H, Sedgwick JB, Vrtis RF, Busse WW. The effect of transendothelial migration on eosinophil function. Am J Respir Cell Mol Biol. 2000; 23:379-388. [PubMed: 10970830]

60. Beninati W, Derdak S, Dixon PF, Grider DJ, Strollo DC, Hensley RE, et al. Pulmonary eosinophils express HLA-DR in chronic eosinophilic pneumonia. J Allergy Clin Immunol. 1993; 92:442-449. [PubMed: 8360395]

61. Hansel TT, Braunstein JB, Walker C, Blaser K, Bruijnzeel PL, Virchow JC Jr, et al. Sputum eosinophils from asthmatics express ICAM-1 and HLA-DR. Clin Exp Immunol. 1991; 86:271277. [PubMed: 1682072]

62. Sedgwick JB, Calhoun WJ, Vrtis RF, Bates ME, McAllister PK, Busse WW. Comparison of airway and blood eosinophil function after in vivo antigen challenge. J Immunol. 1992; 149:37103718. [PubMed: 1358975]

63. Mawhorter SD, Kazura JW, Boom WH. Human eosinophils as antigen-presenting cells: relative efficiency for superantigen- and antigen-induced CD4 ${ }^{+}$T-cell proliferation. Immunology. 1994; 81:584-591. [PubMed: 7518797]

64. Liu LY, Mathur SK, Sedgwick JB, Jarjour NN, Busse WW, Kelly EA. Human airway and peripheral blood eosinophils enhance Th1 and Th2 cytokine secretion. Allergy. 2006; 61:589-597. [PubMed: 16629789]

65. Weller PF, Rand TH, Barrett T, Elovic A, Wong DT, Finberg RW. Accessory cell function of human eosinophils. HLA-DR-dependent, MHC-restricted antigen-presentation and IL-1 alpha expression. J Immunol. 1993; 150:2554-2562. [PubMed: 8450230]

66. Handzel ZT, Busse WW, Sedgwick JB, Vrtis R, Lee WM, Kelly EA, et al. Eosinophils bind rhinovirus and activate virus-specific T cells. J Immunol. 1998; 160:1279-1284. [PubMed: 9570544]

67. Amsen D, Blander JM, Lee GR, Tanigaki K, Honjo T, Flavell RA. Instruction of distinct CD4 T helper cell fates by different notch ligands on antigen-presenting cells. Cell. 2004; 117:515-526. [PubMed: 15137944]

68. Liotta F, Frosali F, Querci V, Mantei A, Fili L, Maggi L, et al. Human immature myeloid dendritic cells trigger a TH2-polarizing program via Jagged-1/Notch interaction. J Allergy Clin Immunol. 2008; 121:1000-1005. e8. [PubMed: 18313135]

69. Maekawa Y, Tsukumo S, Chiba S, Hirai H, Hayashi Y, Okada H, et al. Delta1-Notch3 interactions bias the functional differentiation of activated $\mathrm{CD}^{+}{ }^{+} \mathrm{T}$ cells. Immunity. 2003 ; 19:549-559. [PubMed: 14563319] 
70. Mukherjee S, Schaller MA, Neupane R, Kunkel SL, Lukacs NW. Regulation of T cell activation by Notch ligand, DLL4, promotes IL-17 production and Rorc activation. J Immunol. 2009; 182:7381-7388. [PubMed: 19494260]

71. Okamoto M, Matsuda H, Joetham A, Lucas JJ, Domenico J, Yasutomo K, et al. Jagged1 on dendritic cells and Notch on $\mathrm{CD}^{+}{ }^{+} \mathrm{T}$ cells initiate lung allergic responsiveness by inducing IL-4 production. J Immunol. 2009; 183:2995-3003. [PubMed: 19667086]

72. Radke A, Reynolds LE, Melo RCN, Dvorak AM, Weller PF, Spencer LA. Mature human eosinophils express functional Notch ligands mediating eosinophil autocrine regulation. Blood. 2009; 113:3092-3101. [PubMed: 19171875]

73. Wong CK, Hu S, Cheung PF, Lam CW. TSLP induces chemotactic and pro-survival effects in eosinophils: implications in allergic inflammation. Am J Respir Cell Mol Biol. 2009

74. van Reijsen FC, Bruijnzeel-Koomen CA, de Weger RA, Mudde GC. Retention of long-lived, allergen-specific T cells in atopic dermatitis skin-letter. J Invest Dermatol. 1997; 108:530. [PubMed: 9077487]

75. Prescott SL, Macaubas C, Smallacombe T, Holt BJ, Sly PD, Holt PG. Development of allergenspecific T-cell memory in atopic and normal children. Lancet. 1999; 353:196-200. [PubMed: 9923875]

76. Mojtabavi N, Dekan G, Stingl G, Epstein MM. Long-lived Th2 memory in experimental allergic asthma. J Immunol. 2002; 169:4788-4796. [PubMed: 12391188]

77. Neves JS, Perez SA, Spencer LA, Melo RC, Reynolds L, Ghiran I, et al. Eosinophil granules function extracellularly as receptor-mediated secretory organelles. Proc Natl Acad Sci USA. 2008; 105:18478-18483. [PubMed: 19017810]

78. Sokol CL, Chu NQ, Yu S, Nish SA, Laufer TM, Medzhitov R. Basophils function as antigenpresenting cells for an allergen-induced T helper type 2 response. Nat Immunol. 2009; 10:713720. [PubMed: 19465907]

79. Yoshimoto T, Yasuda K, Tanaka H, Nakahira M, Imai Y, Fujimori Y, et al. Basophils contribute to $\mathrm{T}(\mathrm{H}) 2-\mathrm{IgE}$ responses in vivo via IL-4 production and presentation of peptide-MHC class II complexes to CD4 ${ }^{+}$T cells. Nat Immunol. 2009; 10:706-712. [PubMed: 19465908]

80. Perrigoue JG, Saenz SA, Siracusa MC, Allenspach EJ, Taylor BC, Giacomin PR, et al. MHC class II-dependent basophil-CD4 ${ }^{+} \mathrm{T}$ cell interactions promote $\mathrm{T}(\mathrm{H}) 2$ cytokine-dependent immunity. Nat Immunol. 2009; 10:697-705. [PubMed: 19465906] 


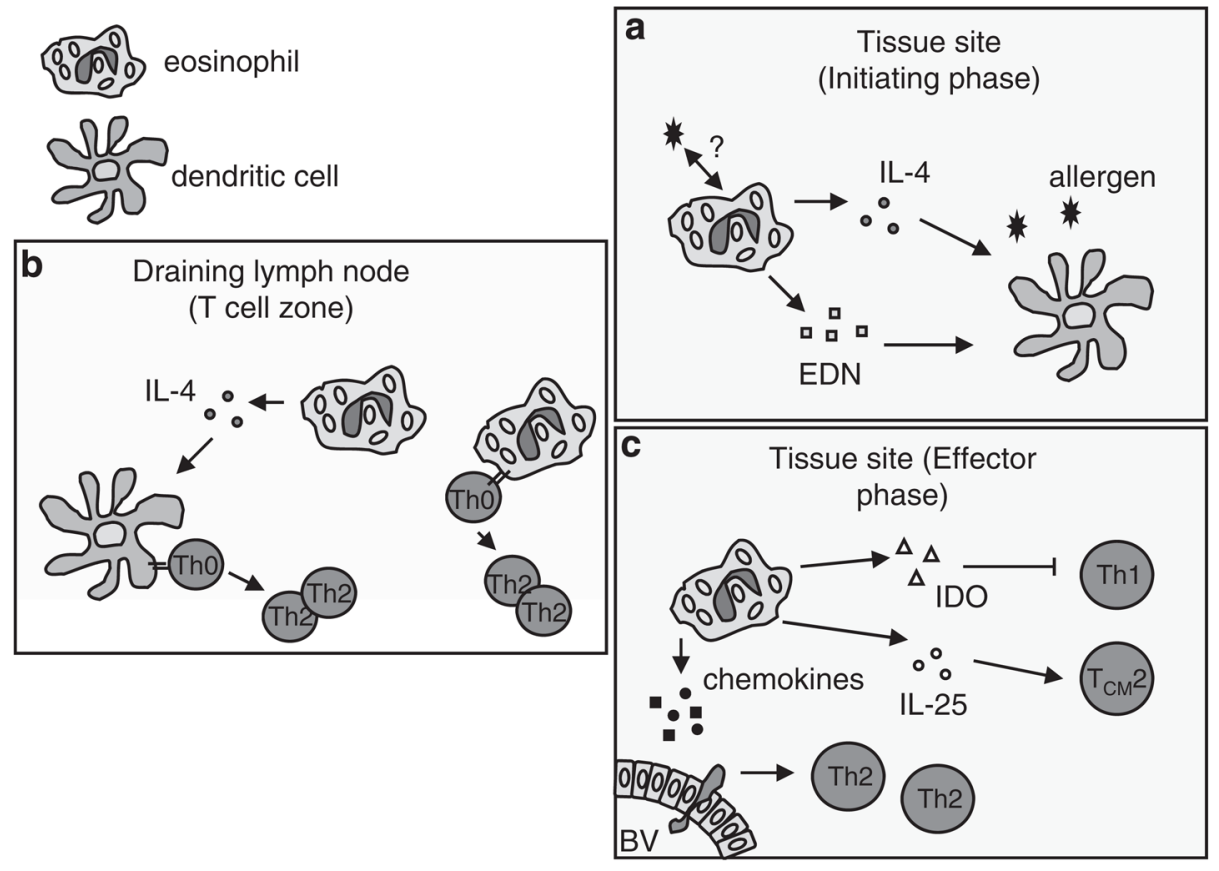

Figure 1.

Eosinophils and Th2 immunity. (a) Eosinophils are one of the first cell types elicited to tissue sites of localized helminths or allergic inflammation, and secrete Th2-inducing cytokines (that is, interleukin (IL)-4) and alarmins (that is, eosinophil-derived neurotoxin, EDN), which exerts it effect on resident dendritic cells (DCs), enhancing DC activation and promoting a Th2-inducing phenotype. (b) Eosinophils traffic from tissue sites to draining lymph nodes, where they localize to T-cell zones. Within lymph nodes eosinophil-derived cytokines promote DC initiation of Th2 polarization, and eosinophils function as antigenpresenting cells to directly instruct Th2 polarization of naive, antigen-specific T cells. (c) Eosinophils within the tissues participate in the effector phases of Th2 immunity by secreting factors that inhibit Th1 lymphocytes (indoleamine 2,3-dioxygenase, IDO) and enhance activities of Th2 memory cells (IL-25). Eosinophils also secrete Th2 chemoattractants required for efficient recruitment of Th2 effector cells into tissue sites. BV, blood vessel. 